OPEN ACCESS

Edited by:

Emma Camp,

University of Technology, Sydney,

Australia

Reviewed by:

Anastazia T. Banaszak,

National Autonomous University of

Mexico, Mexico

Matthew Ryan Nitschke,

University of Technology, Sydney,

Australia

*Correspondence:

Andréa G. Grottol

grottoli.1@osu.edu

Specialty section:

This article was submitted to

Coral Reef Research,

a section of the journal

Frontiers in Marine Science

Received: 26 April 2017

Accepted: 19 June 2017

Published: 04 July 2017

Citation:

Grottoli AG, Tchernov D and Winters G (2017) Physiological and

Biogeochemical Responses of Super-Corals to Thermal Stress from the Northern Gulf of Aqaba, Red Sea.

Front. Mar. Sci. 4:215.

doi: 10.3389/fmars.2017.00215

\section{Physiological and Biogeochemical Responses of Super-Corals to Thermal Stress from the Northern Gulf of Aqaba, Red Sea}

\author{
Andréa G. Grottoli ${ }^{1 *}$, Dan Tchernov ${ }^{2}$ and Gidon Winters ${ }^{3}$ \\ ${ }^{1}$ School of Earth Sciences, Ohio State University, Columbus, OH, United States, ${ }^{2}$ Leon H Charney School of Marine \\ Science, University of Haifa, Haifa, Israel, ${ }^{3}$ The Dead-Sea and Arava Science Center (ADSSC), Tamar Regional Council, Neve \\ Zohar, Israel
}

Mass coral bleaching is increasing in frequency and severity, leading to the loss of coral abundance and diversity. However, some corals are less susceptible to bleaching than others and can provide a model for identifying the physiological and biogeochemical traits that underlie coral resilience to thermal stress. Corals from Eilat in the Gulf of Aqaba in the northern Red Sea do not bleach unless seawater temperatures are sustained at $+6^{\circ} \mathrm{C}$ or higher above their average summer maximum. This extreme thermal tolerance qualifies these as super-corals, as most corals bleach when exposed to temperatures that are only $+1-2^{\circ} \mathrm{C}$ above their thermal maximum. Here, we conducted a controlled bleaching experiment $\left(+6^{\circ} \mathrm{C}\right)$ for 37 days (equivalent to $32^{\circ}$ heating weeks) on three species of corals from Eilat: Stylophora pistillata, Pocillopora damicornis, and Favia favus. To assess the response of the holobiont to thermal stress, the following variables were measured on each coral: endosymbiotic algal cell density, Chlorophyll a, endosymbiotic mitotic cell division, total lipids, protein, carbohydrate, and the stable carbon $\left(\delta^{13} \mathrm{C}\right)$ and oxygen $\left(\delta^{18} \mathrm{O}\right)$ isotopic composition of the skeleton and the $\delta^{13} \mathrm{C}$ of the animal host tissue and endosymbiotic algae. While all three species appeared visibly bleached, their physiological and biogeochemical responses were species-specific. S. pistillata catabolized lipids but still maintained total energy reserves and biomass. Increases in both skeletal $\delta^{13} \mathrm{C}$ and $\delta^{18} \mathrm{O}$ indicates that calcification declined in this species. $P$. damicornis was the least affected by bleaching. It maintained its total energy reserves and biomass, and isotopic evidence suggests that it maintained calcification and was not dependent on heterotrophy for meeting metabolic demand when bleached. Finally, F. favus catabolized protein and carbohydrates, and suffered losses in total energy reserves and biomass. Nevertheless, isotopic evidence suggest that photosynthesis and calcification were maintained, and that this species has a high baseline heterotrophic capacity. Thus, just like their non-super-coral conspecific counterparts, maintaining energy reserves 
and biomass, and heterotrophic capacity appear to be traits that underlie the thermal tolerance of these super-corals from Eilat. Given the high thermal tolerance of these super-corals, these populations could provide viable seed stock for repopulating coral losses on other reefs.

Keywords: coral bleaching, heterotrophy, energy reserves, isotopes, resilience, physiology, biogeochemistry, Red Sea

\section{INTRODUCTION}

Increased atmospheric carbon dioxide $\left(\mathrm{CO}_{2}\right)$ is causing the oceans to warm and to become more acidic. Over the course of this century, tropical seawater temperatures are expected to rise by $1-3^{\circ} \mathrm{C}$ coupled with a drop in $\mathrm{pH}$ of $0.2-0.4$ (IPCC, 2013). At this rate, tropical reefs are expected to experience significant declines in coral abundance, coral diversity, and reef growth during the second half of this century (e.g., HoeghGuldberg et al., 2007; Eakin et al., 2009; Veron et al., 2009; HoeghGuldberg, 2011). While coral calcification is projected to decline by $5 \%$ by 2034 , severe bleaching will be annual by 2030 in some regions and globally by 2055 (van Hooidonk et al., 2014). Recent studies have shown that the warming of tropical oceans is a much more immediate threat to the survival of coral reefs than is ocean acidification (e.g., Cantin et al., 2010; Frieler et al., 2012; Chua et al., 2013). Corals can survive slight decreases in calcification, but it is not likely that they can physiologically survive severe bleaching on an annual basis.

Elevated temperatures can cause corals to bleach: a physiological response to sustained elevated temperatures that results in a breakdown of the coral symbiosis, the loss of the coral's algal endosymbiont partners, which results in a white appearance. The consequences of bleaching to the coral are reduced coral growth, disease, reduced fertility, and death (e.g., Brown, 1997; Hoegh-Guldberg, 1999; Omori et al., 1999; Buddemeier et al., 2004; Tchernov et al., 2011). The frequency of bleaching events appears to be increasing (Eakin et al., 2009; Heron et al., 2016) and back-to-back bleaching years have been observed on basin-wide scales (coralreefwatch.noaa.gov). Annual bleaching is predicted to occur by 2030 in some regions (van Hooidonk et al., 2013, 2014), resulting in large coral losses.

Interestingly, there are corals that are less susceptible to and/or recover more quickly from bleaching (e.g., Loya et al., 2001; Grottoli et al., 2006, 2014; Fine et al., 2013). Resilience to bleaching has been associated with high energy reserves, heterotrophic plasticity, and endosymbiont type (Rowan et al., 1997; Baker et al., 2004; Tchernov et al., 2004; Berkelmans and van Oppen, 2006; Grottoli et al., 2006, 2014; Rodrigues and Grottoli, 2007; Anthony et al., 2009; Guest et al., 2012). Corals with elevated levels of energy reserves (i.e., lipids, protein, carbohydrates) either take longer to bleach, bleach less severely, and/or recover more quickly from bleaching than corals with lower energy reserves because they have an energy source to buffer them against losses in photosynthetically derived fixed carbon (e.g., Rodrigues and Grottoli, 2007; Anthony et al., 2009;
Grottoli et al., 2014; Schoepf et al., 2015). Corals that increase their intake of heterotrophic carbon (i.e., zooplankton, dissolved and particulate organic carbon) or increase the proportionate contribution of heterotrophic vs. photoautotrophic carbon in their tissues when bleached, are able to partially or fully supplement the deficit in their carbon budgets due to declines in photosynthesis when bleached, and are able to recover more quickly from bleaching (Grottoli et al., 2006, 2014; Rodrigues and Grottoli, 2006; Palardy et al., 2008; Levas et al., 2013, 2016). Corals that are able to shuffle or switch their dominant endosymbiont type for a thermally tolerant one are less sensitive to repeat exposures to thermal stress (e.g., Rowan et al., 1997; Baker et al., 2004; Berkelmans and van Oppen, 2006; Grottoli et al., 2014). In addition, there are regions such as the northern region of the Gulf of Aqaba, where entire communities of corals can already tolerate extreme warming conditions, thought the underlying traits that produce that extreme tolerance is poorly understood. These corals may provide seed stock for restoring dying reefs as well as be a model system for identifying the physiological and biogeochemical traits that underlie coral resilience to thermal stress.

Corals in the northern tip of the Gulf of Aqaba in the Red Sea do not bleach when exposed to temperatures that are $\geq 6^{\circ} \mathrm{C}$ above their average summer time maximum temperatures for 3-4 weeks (Fine et al., 2013) coupled with extreme salinities of $41 \mathrm{ppt}$ (Paldor and Anati, 1979). This is remarkable resilience to extreme increases in seawater temperature given that most corals bleach when seawater temperatures exceed summertime maximum temperature by as little as $1-2^{\circ} \mathrm{C}$ for as little as $2-4$ weeks (e.g., Hoegh-Guldberg, 2011). Fine et al. (2013) proposed that this extreme thermal tolerance in these northern Red Sea corals is due to natural selection processes on the larvae transported to the northern section of the Gulf of Aqaba through the very hot straights of Bab el Mandeb in the southern Red Sea. However, the underlying physiological traits responsible for the resilience of these corals is not fully understood. We hypothesized that like their less thermally tolerant counterparts, maintenance of energy reserves and biomass, as well as heterotrophic plasticity, are all traits responsible for extreme temperature tolerance in super-corals of the northern Gulf of Aqaba. To test this hypothesis, bleaching was induced by thermal stress in an experiment conducted on three species of corals (Stylophora pistillata, Pocillopora damicornis, and Favia favus) from the Gulf of Aqaba near Eilat, Israel and the physiological and biogeochemical responses of the host and algal endosymbiont were assessed. 


\section{MATERIALS AND METHODS}

Two fragments from five healthy colonies of S. pistillata and $P$. damicornis $(5-7 \mathrm{~cm}$ tall), and two fragments for seven healthy colonies of $F$. favus (6-8 cm in diameter) were collected between $2 \mathrm{~m}$ and $4 \mathrm{~m}$ depth in the Gulf of Eilat (northern Gulf of Aqaba), Israel $\left(29^{\circ} 30^{\prime} 5.55^{\prime \prime} \mathrm{N}, 34^{\circ} 55^{\prime} 2.49^{\prime \prime} \mathrm{E}\right)$ in mid-February 2005 and glued to labeled gray PVC tiles using underwater epoxy putty. All three species are common in this region. S. pistillata is a branching coral, a reproductive brooder, and is dominated by the endosymbiont Symbiodinium clade A (Shlesinger and Loya, 1985; Karako-Lampert et al., 2004; Winters et al., 2009; Byler et al., 2013; Ziegler et al., 2017). P. damicornis is also a branching coral, is a member of a genus that reproduces by both broadcasting and brooding (though spawning has never been documented for this species in the Red Sea), and is dominated by the endosymbiont Symbiodinium clade C (Shlesinger and Loya, 1985; KarakoLampert et al., 2004; Fine et al., 2013; Sawall et al., 2015; Ziegler et al., 2017). F. favus is a mounding coral, a broadcast spawner, and dominated by the endosymbiont Symbiodinium clade C (Shlesinger and Loya, 1985; Karako-Lampert et al., 2004; Fine et al., 2013). Symbiodinium clade D has never been reported for healthy or bleached corals in this region (Fine et al., 2013).

One fragment from each colony was placed in each of two 95liter outdoor flow-through seawater tanks at the Interuniversity Institute for Marine Science of Eilat, Israel at the northern tip of the Gulf of Aqaba, Red Sea, and allowed to acclimate to the tanks and recover for 2 weeks. The tanks were shaded with black shading nets to simulate photosynthetically active radiation levels at collection depth, and the seawater was filtered through a small coarse gravel filter (70-200 $\mu \mathrm{m}$ pore size), allowing only small organic particulates and dissolved organics into the tanks. Thus, heterotrophic food sources available to the corals were limited to dissolved and particulate organic matter that came through the tank system. Coral were not supplemented with zooplankton. Flow rates were maintained in each tank at $2 \mathrm{l} / \mathrm{min}$ allowing each tank to fully flush every $47 \mathrm{~min}$. On 28 February 2005, the seawater temperature was gradually increased over 3days using three 300W ATMAN aquarium heaters per tank yielding an average daily temperature of $32^{\circ} \mathrm{C}$, while the second tank remained at ambient seawater temperature as controls with an average temperature of $26^{\circ} \mathrm{C}$. The rate of temperature increase in the $32^{\circ} \mathrm{C}$ tank was chosen to minimize heat shock and also get the tank up to temperature relatively quickly. Since these corals are very tolerant of elevated temperatures, the rate of increase was not detrimental to these corals. The original temperature logger data has been lost, but the typical standard deviation of average daily temperatures in experimental tanks at the institute are $\pm 0.5^{\circ} \mathrm{C}$. On 6 April 2005 (37 days later), the fragments were collected, frozen at $-80^{\circ} \mathrm{C}$, and shipped frozen to the Grottoli laboratory for analyses. In the lab, a quarter of each fragment was used for the following analyses: (1) chlorophyll $a$ (Chl a) concentration, (2) total lipid, soluble animal protein, and soluble animal carbohydrate concentrations, (3) endosymbiotic algae concentrations and mitotic indexes, and (4) stable isotopic analyses of the host tissue, endosymbiotic algae, and underlying skeleton.

\section{Algal Endosymbiont Analyses and Coral Energy Reserves}

Chl $a$ was extracted from ground samples in 100\% acetone and the absorbance measured at 663 and $630 \mathrm{~nm}$ wavelengths using a Spectronic 20 Genesis visible spectrophotometer. The Chl $a$ concentration was calculated using equations from Jeffrey and Humphrey (1975) corrected for turbidity with the absorbance value measured at $750 \mathrm{~nm}$. Algal endosymbionts were separated from the animal tissue by centrifugation and three subsamples were counted with a hemocytometer and light microscope. The total number of algal cells and the number of mitotically dividing algal cells were recorded.

Total lipids were extracted in a 2:1 chloroform/methanol solution, washed in $0.88 \% \mathrm{KCl}$, and then dried to a constant weight (method modified from Grottoli et al., 2004). Soluble animal protein was extracted using the bicinchoninic acid method (Smith et al., 1985) with bovine serum albumin as a standard (Pierce BCA Protein Assay Kit). Soluble animal carbohydrate was extracted using the phenol-sulfuric acid method (Dubois et al., 1956) with glucose as a standard. All analyses were made from whole ground coral samples, converted into Joules (Gnaiger and Bitterlich, 1984), and standardized to both grams of ash free dry weight (gdw) and to surface area as measured using the aluminum foil technique (Marsh, 1970). However, normalization to ash free dry weight is more robust when comparing species with different tissue depths, morphology, and polyp structure than the same data normalized to surface area (Edmunds and Gates, 2002). Therefore, only results of data standardized to ash free dry weight are reported here (However, note that all statistics were also performed on the area normalized data and yielded almost identical patterns). Total energy reserves were calculated as the sum of total lipids, proteins, and carbohydrates. Total dry biomass was standardized to surface area. These analytical methods have been successfully used in corals before (e.g., Rodrigues and Grottoli, 2007).

\section{Stable Isotopic Analyses}

Coral tissue was completely removed from the skeleton using a Water-pik (Johannes and Wiebe, 1970). The tissue slurry was separated into animal host and algal endosymbiont fractions by centrifugation using established methods (Rodrigues and Grottoli, 2006). Briefly, coral slurry was homogenized to break open the animal cells, then centrifuged at $4,000 \mathrm{rpm}$ for 5 min to separate the animal host and endosymbiotic algal fraction. The supernatant (i.e., animal host) was decanted and the algal pellet resuspended in deionized water and centrifuged again to remove any remaining animal host particles. The supernatants from both centrifugations were combined. Each organic fraction was isolated onto a pre-burned glass fiber filter under vacuum, and individually combusted in a Costech Elemental Analyzer. The resulting $\mathrm{CO}_{2}$ gas was analyzed for ${ }^{13} \mathrm{C}\left[\delta^{13} \mathrm{C}=\right.$ permil deviation of ${ }^{13} \mathrm{C}:{ }^{12} \mathrm{C}$ relative to Vienna Peedee Belemnite Limestone standard (VPDB)] with a Thermo Delta Advantage IV via a Thermo ConFlow III open split in the Grottoli lab. At least $10 \%$ of all samples were run in duplicate. The standard deviation of repeated measurements of the USGS24 
standard for $\delta^{13} \mathrm{C}$ was $\pm 0.08 \%$. The host tissue isotope values were reported as $\delta^{13} \mathrm{C}_{\mathrm{h}}$ while the algal endosymbiont isotope data were reported as $\delta^{13} \mathrm{C}_{\mathrm{e}}$. In general, as the incorporation of isotopically depleted zooplankton and other heterotrophic carbon sources (i.e., dissolved and particulate organic carbon) into coral tissues increases, the $\delta^{13} \mathrm{C}_{\mathrm{h}}$ decreases (Rodrigues and Grottoli, 2006; Levas et al., 2013; Schoepf et al., 2015). As the rate of photosynthesis increases, isotopic fractionation decreases, and endosymbiotic algae incorporate relatively less ${ }^{12} \mathrm{C}$ than ${ }^{13} \mathrm{C}$ into their tissues, resulting in increased $\delta^{13} \mathrm{C}_{\mathrm{e}}$ (Muscatine et al., 1989; Rodrigues and Grottoli, 2006). The difference between the $\delta^{13} \mathrm{C}_{\mathrm{h}}$ and $\delta^{13} \mathrm{C}_{\mathrm{e}}$ were also calculated to assess the proportionate contribution of heterotrophy and photoautotrophy in the carbon budget (sensu Muscatine et al., 1989). Specifically, decreases in $\delta^{13} C_{h}-\delta^{13} C_{e}$ are interpreted to mean that the proportionate contribution of heterotrophic carbon to coral tissues has increased.

The skeleton was prepared for $\delta^{13} \mathrm{C}\left(\delta^{13} \mathrm{C}_{\mathrm{s}}\right)$ and $\delta^{18} \mathrm{O}$ $\left(\delta^{18} \mathrm{O}_{\mathrm{s}}\right)\left[\delta^{18} \mathrm{O}=\right.$ permil deviation of ${ }^{18} \mathrm{O}:{ }^{16} \mathrm{O}$ relative to VPDB $]$ analysis by shaving the top $100-200 \mu \mathrm{m}$ of skeletal material off the tip of each coral fragment using a Dremel tool with a diamond-tipped drill bit. Approximately $\sim 80 \mu \mathrm{g}$ of skeletal material was acidified with $100 \%$ ortho-phosphoric acid in an automated Kiel III carbonate device, and the $\delta^{13} \mathrm{C}$ and $\delta^{18} \mathrm{O}$ values of the resulting $\mathrm{CO}_{2}$ were measured using a Finnigan MAT 252 mass spectrophotometer at Stanford University. At least $10 \%$ of all samples were run in duplicate. The standard deviation of repeated measurements of an internal standard was $\pm 0.03 \%$ for $\delta^{13} \mathrm{C}$ and $\pm 0.05 \%$ for $\delta^{18} \mathrm{O}$. Skeletal values were reported as $\delta^{13} \mathrm{C}_{\mathrm{s}}$ and $\delta^{18} \mathrm{O}_{\mathrm{s}}$. In general, as the rate of photosynthesis increases or as the incorporation of heterotrophic carbon into coral tissues decreases, the pool of inorganic $\mathrm{C}$ available for calcification through animal respiration becomes enriched resulting in increased $\delta^{13} \mathrm{C}_{\mathrm{s}}$ (Grottoli and Wellington, 1999; Grottoli, 2002). In addition, variability in $\delta^{18} \mathrm{O}_{s}$ results from temperature-induced kinetic fractionation and seawater $\delta^{18} \mathrm{O}$ (Epstein et al., 1953). As temperature increases, $\delta^{18} \mathrm{O}_{\mathrm{s}}$ decreases (Weber and Woodhead, 1972; Kim and O'Neil, 1997). Since seawater $\delta^{18} \mathrm{O}_{\mathrm{s}}$ is constant in this study because the source seawater was the same in all tanks, it did not influence the $\delta^{18} \mathrm{O}_{\mathrm{s}}$ values.

\section{Statistical Analysis}

Univariate two-way analysis of variance (ANOVA) was used to test the effects of species and temperature on Chl $a$, algal endosymbiont, mitotic index, lipid, protein, carbohydrate, total energy reserves, and tissue biomass concentrations as well as $\delta^{13} \mathrm{C}_{\mathrm{s}}, \delta^{18} \mathrm{O}_{\mathrm{s}}, \delta^{13} \mathrm{C}_{\mathrm{h}}, \delta^{13} \mathrm{C}_{\mathrm{e}}$, and $\delta^{13} \mathrm{C}_{\mathrm{h}}-\delta^{13} \mathrm{C}_{\mathrm{e}}$. Prior to statistical analysis, all data was tested for normality using a ShapiroWilk's test and homogeneity of variance was assessed with plots of expected vs. residual values. Any data failing to meet this assumption was log transformed and then met the assumptions of normal distribution. A posteriori slice tests (i.e., tests of simple effects, Winer, 1971) determined if bleached and control averages significantly differed within species. Bonferroni corrections were not used due to increased likelihood of false negatives (Quinn and Keough, 2002). With only one tank for treatment and one tank for controls, we were unable to assess tank effects independent of treatment effects. However, every aspect of both tanks that were measured were the same (i.e., seawater source, flow, light, position relative to the sun's arc) except for temperature. In addition, one bleached $P$. damicornis and two control $F$. favus fragments were lost during shipping or storage, yielding an unbalanced number of samples in the treatment and controls for these two species. Statistical analyses were generated using SAS software, Version 8.02 of the SAS System for Windows. Values of $p<0.05$ were considered significant.

To get an overall assessment of the effect of treatment across all variables, non-parametric multi-variate statistics were employed. The non-parametric analyses were conducted on three sub-sets of the data: (1) all of the physiology data, (2) all of the isotopic data, and (3) all of the physiology and isotopic data combined. Since two samples did not have isotopic data, the multi-variate analyses that included the isotopes were comprised of 29 corals whereas the analyses of the physiological variables alone included 31 corals. Euclidean-distance based resemblance matrix was constructed using normalized data of all of the measured variables. Non-parametric multidimensional scaling (NMDS) plots were generated to graphically represent relationships between each coral sample across all treatments and species. Analysis of similarities (ANOSIM) was then used to test for the effect of species and treatment. ANOSIM simultaneously uses all variables measured, and tests whether all data (i.e., all physiological and/or isotopic) from one coral group differs from another coral group. The ANOSIM pairwise test statistic $\mathrm{R}$ ranges from 0 (no difference and complete overlap between groups) to 1 (maximum difference and no overlap between groups) and is a strong indicator of separation between groups, especially at low sample sizes such as in this study, as long as the overall ANOSIM test statistic R is significant (Clarke and Gorley, 2006). Multivariate analyses were conducted using the software package Primer V6, and for the ANOSIMs a $p<0.05$ was considered significant. Finally, since fragments pairs of each colony were included in both treatments, differences between treatment and control for any variable were due to treatment alone, independent of genotype.

\section{RESULTS}

The temperature exposure of the treatment corals was equivalent to $32^{\circ}$ heating weeks ( $\mathrm{DHW}$ ) (coralreefwatch.noaa.gov) relative to the controls. All three species in the elevated temperature treatment (i.e., $32^{\circ} \mathrm{C}$ ) appeared pale or white and as such were bleached, whereas all of the corals in the control treatment (i.e., $26^{\circ} \mathrm{C}$ ) were brown in color and appeared non-bleached.

\section{Endosymbiotic Algae}

Average endosymbiotic algal concentrations dropped to 5, 49, and $19 \%$ of control concentrations in S. pistillata, P. damicornis, and F. favus, respectively (Table 1, Figure 1A). At the same time, Chl a concentrations in bleached S. pistillata and P. damicornis decreased to 37 and 33\% of control values, respectively (Table 1, Figure 1B), and mitotic divisions were 26-fold lower in bleached S. pistillata and 9-fold lower in bleached F. favus corals relative to 
TABLE 1 | Results of three two-way ANOVAs testing for the effect of species (S), and temperature $(\mathrm{T})$ on average chlorophyll a concentration, endosymbiotic algal density and mitotic index.

\begin{tabular}{llllrr}
\hline Species & Effect & $\boldsymbol{d} \boldsymbol{f}$ & SS & $\boldsymbol{F}$ & \multicolumn{1}{c}{$\boldsymbol{p}$} \\
\hline Endosymbiontic & Model & 5 & 5.8798 & 18.86 & $\mathbf{0 . 0 0 0 1}$ \\
Algal density & $\mathrm{S}$ & 2 & 0.4347 & 3.49 & $\mathbf{0 . 0 4 6 2}$ \\
& $\mathrm{T}$ & 1 & 4.4111 & 70.76 & $<\mathbf{0 . 0 0 0 1}$ \\
& $\mathrm{S} \times \mathrm{T}$ & 2 & 0.8797 & 7.06 & $\mathbf{0 . 0 0 3 7}$ \\
Chlorophyll a & Model & 5 & 14932873 & 18.13 & $\mathbf{0 . 0 0 0 1}$ \\
& $\mathrm{S}$ & 2 & 7111311 & 21.59 & $\mathbf{0 . 0 0 0 1}$ \\
& $\mathrm{T}$ & 1 & 5460974 & 33.16 & $<\mathbf{0 . 0 0 0 1}$ \\
& $\mathrm{S} \times \mathrm{T}$ & 2 & 2169097 & 6.59 & $\mathbf{0 . 0 0 5 0}$ \\
Mitotic Index & $\mathrm{Model}$ & 5 & 7.8572 & 12.78 & $\mathbf{0 . 0 0 0 1}$ \\
& $\mathrm{S}$ & 2 & 0.0875 & 3.28 & 0.0541 \\
& $\mathrm{~T}$ & 1 & 5.3524 & 43.54 & $<\mathbf{0 . 0 0 0 1}$ \\
& $\mathrm{S} \times \mathrm{T}$ & 2 & 1.1424 & 4.65 & $\mathbf{0 . 0 1 9 2}$
\end{tabular}

Effects of species (S) and temperature (T) were fixed and fully crossed. Endosymbiontic algal concentration and mitotic index values were log transformed to meet assumptions of normal distribution before ANOVA analysis. df, degrees of freedom; SS, type III sum of squares of the main effects. Significant effects are in bold.

their controls (Table 1, Figure 1C). While endolithic algae were not present in noticeable quantities in either $P$. damicornis or S. pistillata, F. favus showed evidence of harboring endolithic algae. Because all samples of $F$. favus showed approximately the same quantity of endolithic algae irrespective of treatment, it was assumed that their contribution to Chl $a$ was relatively constant and that any differences in Chl $a$ between the bleached and control fragments was due to the bleaching effect alone.

\section{Energy Reserves}

While lipids and protein were unaffected by bleaching overall, a posteriori slice tests revealed that lipid concentrations in bleached $S$. pistillata and protein concentrations in bleached $F$. favus were 49 and $48 \%$ lower, respectively, than in their controls (Table 2, Figures 2A,B). Carbohydrate concentrations dropped to 40 and $41 \%$ of control values in bleached P. damicornis and F. favus, respectively (Table 2, Figure 2C). Despite losses of at least one component of energy reserves in each species, only bleached $F$. favus had significantly lower total energy reserves ( $43 \%$ decrease) and experienced a $27 \%$ decrease in biomass compared to controls at the species level (Table 2, Figures 2D,E).

\section{Stable Isotopes}

Average $\delta^{13} C_{s}$ values were significantly higher in bleached than in control corals overall (Table 3), but this difference was only significant at the species level for S. pistillata where bleached $\delta^{13} \mathrm{C}_{\mathrm{s}}$ was $1.7 \%$ higher than control corals (Table 3, Figure 3A). Average $\delta^{18} \mathrm{O}_{s}$ was $0.9 \%$ higher in the bleached than in control S. pistillata (Table 3, Figure 3B). At the same time, average $\delta^{13} \mathrm{C}_{\mathrm{h}}$ values were $2.2 \%$ and $1.8 \%$ higher in bleached than in control $S$. pistillata and $F$. favus (Table 3, Figure 3C), respectively, while average $\delta^{13} \mathrm{C}_{\mathrm{e}}$ values were $1.0 \%$ higher in bleached than in control F. favus, and at least $2.4 \%$ higher in F. favus overall compared to the other two species (Table 3, Figure 3D). Finally, average $\delta^{13} C_{h}-\delta^{13} C_{e}$ values were $0.8 \%$ higher in bleached than

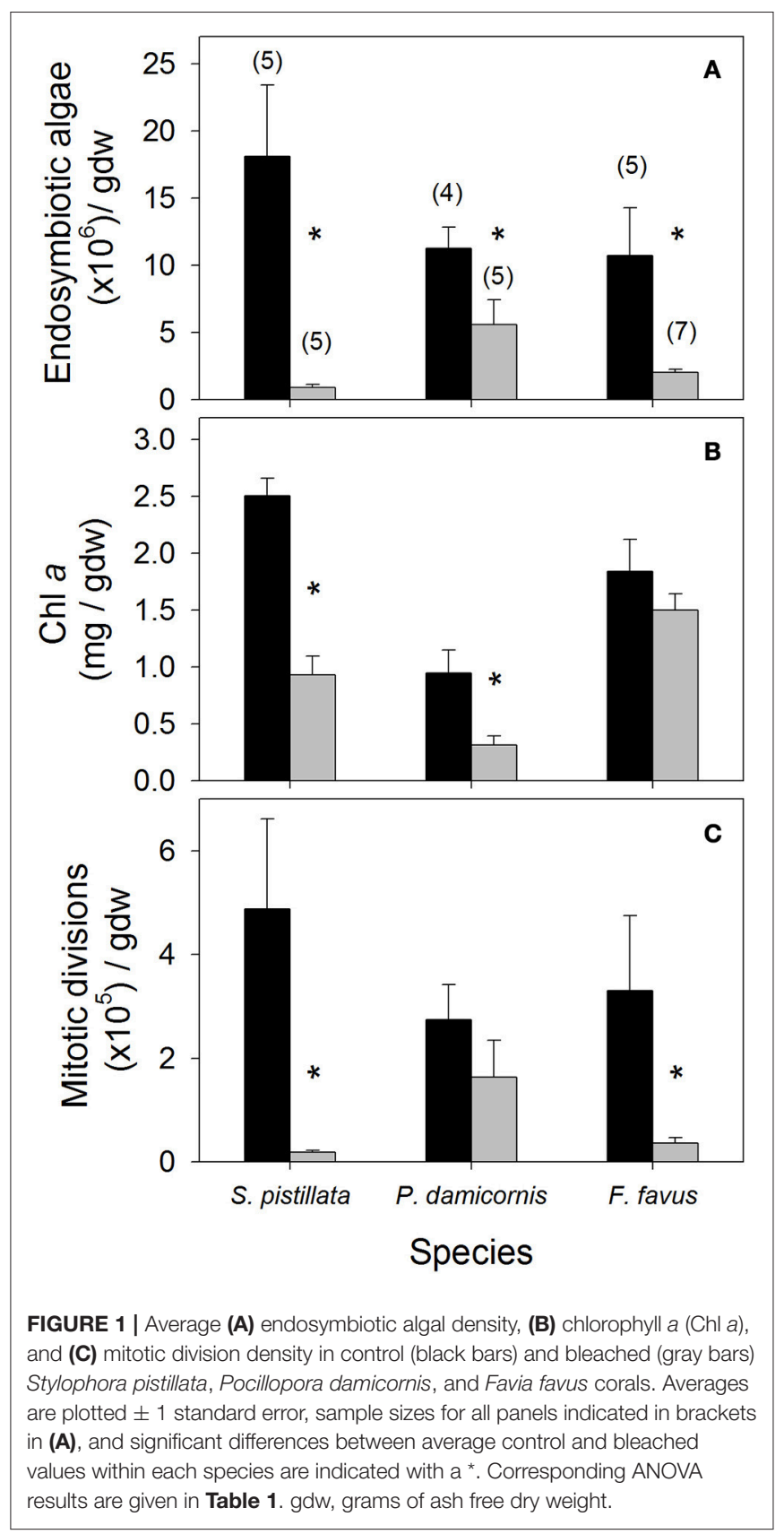

in control corals overall (Table 3), but this difference was only significant at the species level for S. pistillata where the average $\delta^{13} \mathrm{C}_{\mathrm{h}}-\delta^{13} \mathrm{C}_{\mathrm{e}}$ was $1.5 \%$ higher in bleached than in control corals (Figure 4).

\section{Multi-Variate Assessments}

Overall, both bleached $S$. pistillata and F. favus corals significantly differed from their controls, whereas bleached and control $P$. damicornis corals did not differ from each other (Table 4, Figure 5). This was true for all combinations of the data (i.e., physiological variables alone, isotopic variables alone, of both physiological and isotopic data combined). The degree of 
TABLE 2 | Results of five two-way ANOVAs testing for the effect of species (S), and temperature (T) on average lipid, protein, carbohydrate, total energy reserves, and total biomass.

\begin{tabular}{|c|c|c|c|c|c|}
\hline Species & Effect & $d f$ & SS & $F$ & $p$ \\
\hline \multirow[t]{4}{*}{ Lipid } & Model & 5 & $101.51 \times 10^{6}$ & 2.09 & 0.1008 \\
\hline & S & 2 & $16.42 \times 10^{6}$ & 0.84 & 0.4420 \\
\hline & $\mathrm{T}$ & 1 & $16.99 \times 10^{6}$ & 1.75 & 0.1983 \\
\hline & $\mathrm{S} \times \mathrm{T}$ & 2 & $66.51 \times 10^{6}$ & 3.42 & 0.0488 \\
\hline \multirow[t]{4}{*}{ Protein } & Model & 5 & 0.5714 & 2.40 & 0.0660 \\
\hline & S & 2 & 0.4106 & 4.31 & 0.0247 \\
\hline & $\mathrm{T}$ & 1 & 0.1199 & 2.52 & 0.1253 \\
\hline & $S \times T$ & 2 & 0.0796 & 0.84 & 0.4456 \\
\hline \multirow[t]{4}{*}{ Carbohydrate } & Model & 5 & 1.8037 & 11.14 & $<0.0001$ \\
\hline & S & 2 & 0.9926 & 15.33 & $<0.0001$ \\
\hline & $\mathrm{T}$ & 1 & 0.6349 & 19.61 & 0.0002 \\
\hline & $\mathrm{S} \times \mathrm{T}$ & 2 & 0.1912 & 2.95 & 0.0706 \\
\hline \multirow[t]{4}{*}{ Total En Res } & Model & 5 & $61.83 \times 10^{7}$ & 3.14 & 0.0246 \\
\hline & S & 2 & $22.46 \times 10^{7}$ & 2.85 & 0.0765 \\
\hline & $\mathrm{T}$ & 1 & $18.33 \times 10^{7}$ & 4.66 & 0.0407 \\
\hline & $\mathrm{S} \times \mathrm{T}$ & 2 & $22.93 \times 10^{7}$ & 2.91 & 0.0730 \\
\hline \multirow[t]{4}{*}{ Biomass } & Model & 5 & 0.0069 & 8.02 & 0.0001 \\
\hline & S & 2 & 0.0058 & 16.85 & $<0.0001$ \\
\hline & $\mathrm{T}$ & 1 & 0.0000 & 0.23 & 0.6329 \\
\hline & $\mathrm{S} \times \mathrm{T}$ & 2 & 0.0018 & 5.10 & 0.0139 \\
\hline
\end{tabular}

Effects of species (S) and temperature (T) were fixed and fully crossed. Carbohydrate and protein values were log transformed to meet assumptions of normal distribution before ANOVA analysis. df, degrees of freedom; SS, type III sum of squares of the main effects;

Total En Res, total energy reserves. Significant effects are in bold.

separation between the bleached and control corals of both $S$. pistillata and $F$. favus was similar with $\mathrm{R}$ values produced from the physiological and isotopic data combined of 0.66 and 0.64 , respectively. In addition, all species significantly differed from each other, though $F$. favus differed the most from the other two species as indicated by $R>0.7$ when compared to either of the other two species when both the physiological and isotopic data were considered (Table 5, Figure 5).

\section{DISCUSSION}

Overall, all treatment corals bleached (Figure 1), but the degree to which they were physiologically affected by the temperature stress varied among species (Figures 1-5). Here, we discuss the physiological and isotopic responses of each coral species, and explore the implications of those responses to the persistence of corals in the future.

\section{Stylophora pistillata}

S. pistillata bleached the most severely of all three species studied with the greatest percentage drop in endosymbiotic algal density (Figure 1A). Large drops in endosymbiotic algal density are associated with dramatic decreases in photosynthesis, resulting in corals that are unable to meet their total metabolic demand (Grottoli et al., 2006, 2014; Tremblay et al., 2012). Here, S. pistillata catabolized its lipid reserves (Figure 2A), presumably

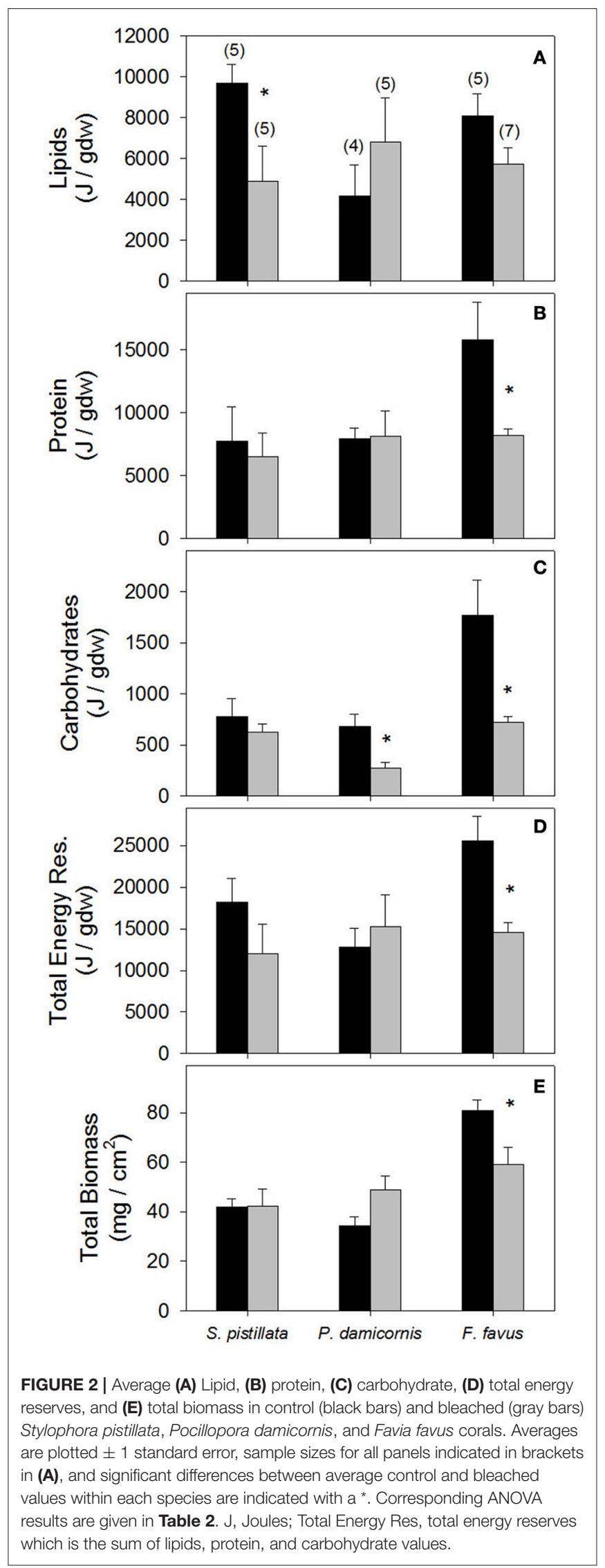


TABLE 3 | Results of five two-way ANOVAs testing for the effect of species (S), and temperature $(\mathrm{T})$ on coral skeletal $\delta^{13} \mathrm{C}$, skeletal $\delta^{18} \mathrm{O}$, host tissue $\delta^{13} \mathrm{C}$, endosymbiontic algal $\delta^{13} \mathrm{C}$, and the difference between host and endosymbiontic algal $\delta^{13} \mathrm{C}\left(\delta^{13} \mathrm{C}_{\mathrm{h}}-\delta^{13} \mathrm{C}_{\mathrm{z}}\right)$.

\begin{tabular}{|c|c|c|c|c|c|}
\hline Species & Effect & $d f$ & SS & $\boldsymbol{F}$ & $p$ \\
\hline \multirow[t]{4}{*}{ Skeletal $\delta^{13} \mathrm{C}$} & Model & 5 & 14.3713 & 4.37 & 0.0060 \\
\hline & $S$ & 2 & 4.5647 & 3.47 & 0.0475 \\
\hline & $\mathrm{T}$ & 1 & 7.1402 & 10.86 & 0.0030 \\
\hline & $\mathrm{S} \times \mathrm{T}$ & 2 & 2.6548 & 2.02 & 0.1548 \\
\hline \multirow[t]{4}{*}{ Skeletal $\delta^{18} \mathrm{O}$} & Model & 5 & 16.4869 & 27.37 & $<0.0001$ \\
\hline & S & 2 & 13.2130 & 54.83 & $<0.0001$ \\
\hline & $\mathrm{T}$ & 1 & 0.5164 & 4.29 & 0.0494 \\
\hline & $\mathrm{S} \times \mathrm{T}$ & 2 & 2.0703 & 8.59 & 0.0015 \\
\hline \multirow[t]{4}{*}{ Host tissue $\delta^{13} \mathrm{C}$} & Model & 5 & 46.6370 & 12.61 & 0.0001 \\
\hline & S & 2 & 21.9482 & 14.83 & $<0.0001$ \\
\hline & $\mathrm{T}$ & 1 & 10.7377 & 14.51 & 0.0009 \\
\hline & $S \times T$ & 2 & 8.5440 & 5.77 & 0.0090 \\
\hline \multirow[t]{4}{*}{ Endosymb. $\delta^{13} \mathrm{C}$} & Model & 5 & 55.8993 & 14.63 & $<0.0001$ \\
\hline & $S$ & 2 & 45.4508 & 29.74 & $<0.0001$ \\
\hline & $\mathrm{T}$ & 1 & 0.3171 & 0.42 & 0.5253 \\
\hline & $S \times T$ & 2 & 4.5973 & 3.01 & 0.0675 \\
\hline \multirow[t]{4}{*}{$\delta^{13} C_{h}-\delta^{13} C_{z}$} & Model & 5 & 14.4986 & 4.33 & 0.0060 \\
\hline & S & 2 & 8.6119 & 6.43 & 0.0058 \\
\hline & $\mathrm{T}$ & 1 & 6.3445 & 9.48 & 0.0051 \\
\hline & $S \times T$ & 2 & 1.3528 & 1.01 & 0.3790 \\
\hline
\end{tabular}

Effects of species (S) and temperature (T) were fixed and fully crossed. df, degrees of freedom; SS, type III sum of squares of the effect; Endosymb., endosymbiotic algae. Significant effects are in bold.

to compensate for losses in photosynthetically fixed carbon. The decline in lipids could have been further exacerbated by the absence of supplemental feeding, since heterotrophic carbon is critical to lipid synthesis in bleached corals (Baumann et al., 2014). Increases in $\delta^{13} \mathrm{C}_{\mathrm{h}}$ (Figure 3C) suggest that the lipids catabolized during bleaching (Figure 2A) were isotopically depleted and/or that in the absence of isotopically depleted zooplankton in the diet, coral tissues became progressively enriched. Given that bleached Hawaiian corals were found to catabolize isotopically enriched lipids (Grottoli and Rodrigues, 2011), it is most likely that the enriched $\delta^{13} \mathrm{C}_{\mathrm{h}}$ observed here in bleached corals is a result of a lack of zooplankton. In addition, increases in $\delta^{13} \mathrm{C}_{\mathrm{h}-\mathrm{e}}$ (Figure 4) suggests that S. pistillata incorporated less heterotrophic $\mathrm{C}$ into its tissues when bleached [i.e., increases (decreases) in $\delta^{13} \mathrm{C}_{\mathrm{h}-\mathrm{e}}$ are indicative of dramatic decreases (increases) in the incorporation of heterotrophic carbon in tissues (Rodrigues and Grottoli, 2006)]. This is consistent with the fact that corals in this study were not fed zooplankton during the experiment. However, even if they had been fed, this species is known to decrease feeding rates on zooplankton, pico-, and nano-plankton, as well as suffer increases in total organic carbon losses when bleached (Ferrier-Pages et al., 2010; Tremblay et al., 2012), and that it has limited heterotrophic plasticity capacity in response to a changing environment (Alamaru et al., 2009). Despite the loss of lipids and isotopic evidence of reduced heterotrophic carbon input, bleached $S$. pistillata only showed a trend of declining total energy reserves $(p<0.13)$ and maintained its biomass (Figures 2D,E). This may be because this species is able to rapidly curb apoptosis and acclimate to sustained thermal stress when exposed to elevated temperatures (Kvitt et al., 2014, 2016).

The increase in $\delta^{13} \mathrm{C}_{\mathrm{s}}$ and $\delta^{18} \mathrm{O}_{\mathrm{s}}$ when bleached (Figures 3A,B) is consistent with decreases in calcification during bleaching (Rodrigues and Grottoli, 2006) due to greater equilibration with seawater DIC when calcification rates drop (McConnaughey, 1989). Increases in $\delta^{13} \mathrm{C}_{\mathrm{s}}$ could also indicate an increase in photosynthesis rates (Grottoli and Wellington, 1999; Grottoli, 2002). However, this is not likely since this species typically experiences significant declines in photochemical efficiency $(\mathrm{Fv} / \mathrm{Fm})$ and photosynthesis rates at elevated temperatures (Tremblay et al., 2012; Fine et al., 2013), and because it is not physiologically possible to increase photosynthesis rates when bleached. In addition, the increase in $\delta^{18} \mathrm{O}_{s}$ deceptively suggests that seawaters were cooler, not hotter, in the bleached coral tank (Figure 3B). Increases in $\delta^{18} \mathrm{O}_{\mathrm{s}}$ in bleached corals are caused by isotopic equilibration with seawater as calcification dramatically slows (Rodrigues and Grottoli, 2006). Thus, the skeletal isotopic signature here indicates a decline in calcification in bleached $S$. pistillata. Decreasing calcification rates is one mechanism by which $S$. pistillata may reduce its energetic demand and maintain total energy reserves and biomass. In principle, maintenance of energy reserves and biomass should confer an advantage to $S$. pistillata and facilitate recovery from bleaching, as has been found for the branching Caribbean coral Porites divaricata (Grottoli et al., 2014).

\section{Pocillopora damicornis}

Of all three species studied here, $P$. damicornis was the least affected by bleaching with the smallest decline in endosymbiont cell density and the only species to maintain mitotic cell division (Figure 1). Fine et al. (2013) showed that photochemical efficiency of PSII in this species is among the least affected by $34^{\circ} \mathrm{C}$ temperatures compared to other corals from this site, despite hosting the typically thermally sensitive clade $\mathrm{C}$ Symbiodinium (Karako-Lampert et al., 2004). At the same time, $P$. damicornis preserved its energy reserves and biomass (Figure 2), showed no metabolic shifts in its isotopic signatures (Figures 3, 4), and overall was unchanged when bleached (Figure 5). The maintenance of its skeletal isotopic values when bleached (Figures 3A,B) suggests that calcification was maintained when bleached (Rodrigues and Grottoli, 2006). This is not an unreasonable interpretation as some populations of Pacific $P$. damicornis corals have optimal calcification rates at $31^{\circ} \mathrm{C}$ (Clausen and Roth, 1975) - only $1^{\circ}$ cooler than the experimental temperatures. The lack of any shifts in $\delta^{13} \mathrm{C}_{\mathrm{h}}$, $\delta^{13} \mathrm{C}_{\mathrm{e}}$, and $\delta^{13} \mathrm{C}_{\mathrm{h}-\mathrm{e}}$ indicate that the proportionate contribution of photoautotrophic and heterotrophic $\mathrm{C}$ to tissues did not change with bleaching. Given that these corals were not fed zooplankton during the experiment, these results further suggest that $P$. damicornis may not be very dependent on heterotrophic $\mathrm{C}$ for meeting metabolic demand or may not be able to change 

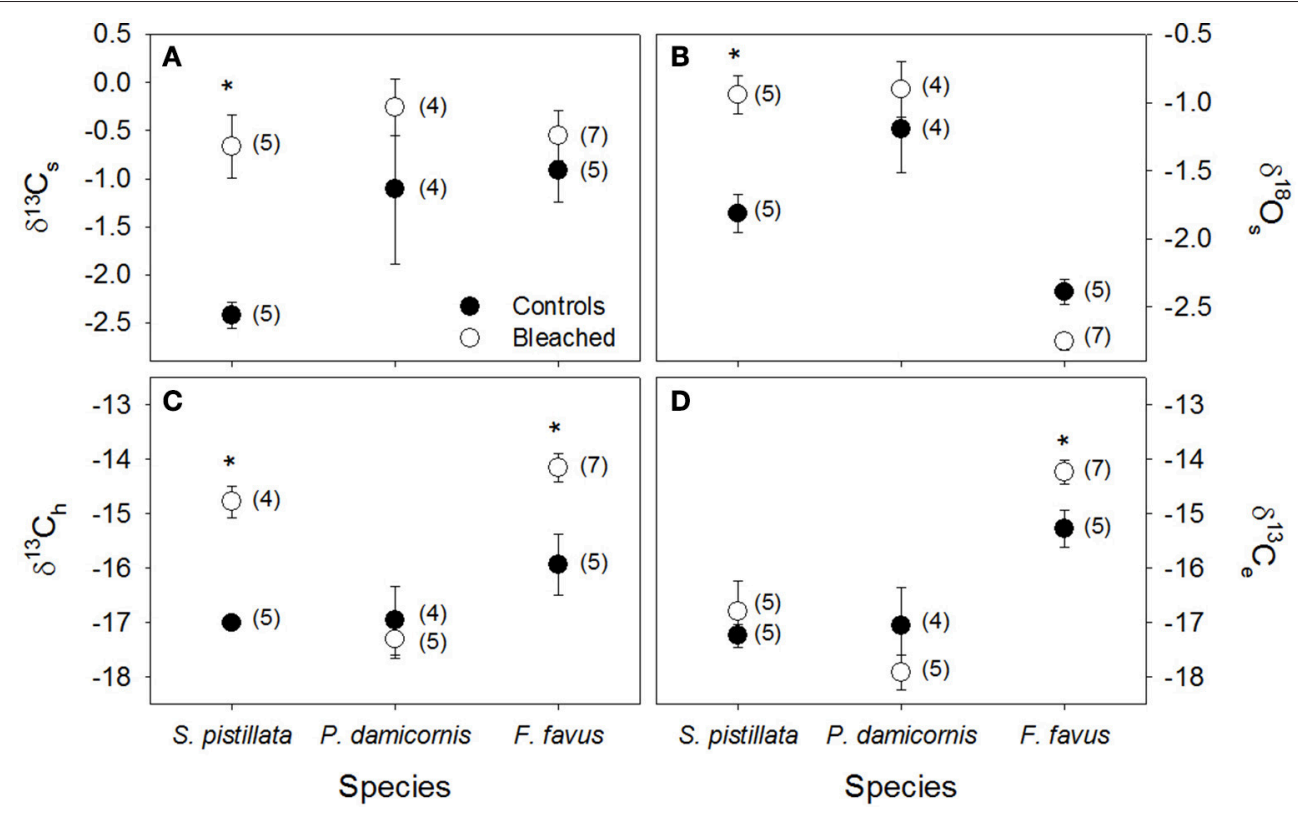

FIGURE 3 | Average stable isotopes in control (black circles) and bleached (white circles) coral skeleton (s), host tissue (h) and algal endosymbiont (e) fractions. (A) $\delta^{13} C_{s}$, (B) $\delta^{18} \mathrm{O}_{s}$, (C) $\delta^{13} C_{h}$, and (D) $\delta^{13} C_{e}$ in Stylophora pistillata, Pocillopora damicornis, and Favia favus corals. All data are reported in permil (\%) relative to V-PDB. Averages are plotted \pm 1 standard error, sample sizes for each average are indicated in brackets, and significant differences between average control and bleached values within each species are indicated with $a^{*}$. Corresponding ANOVA results are given in Table 3.

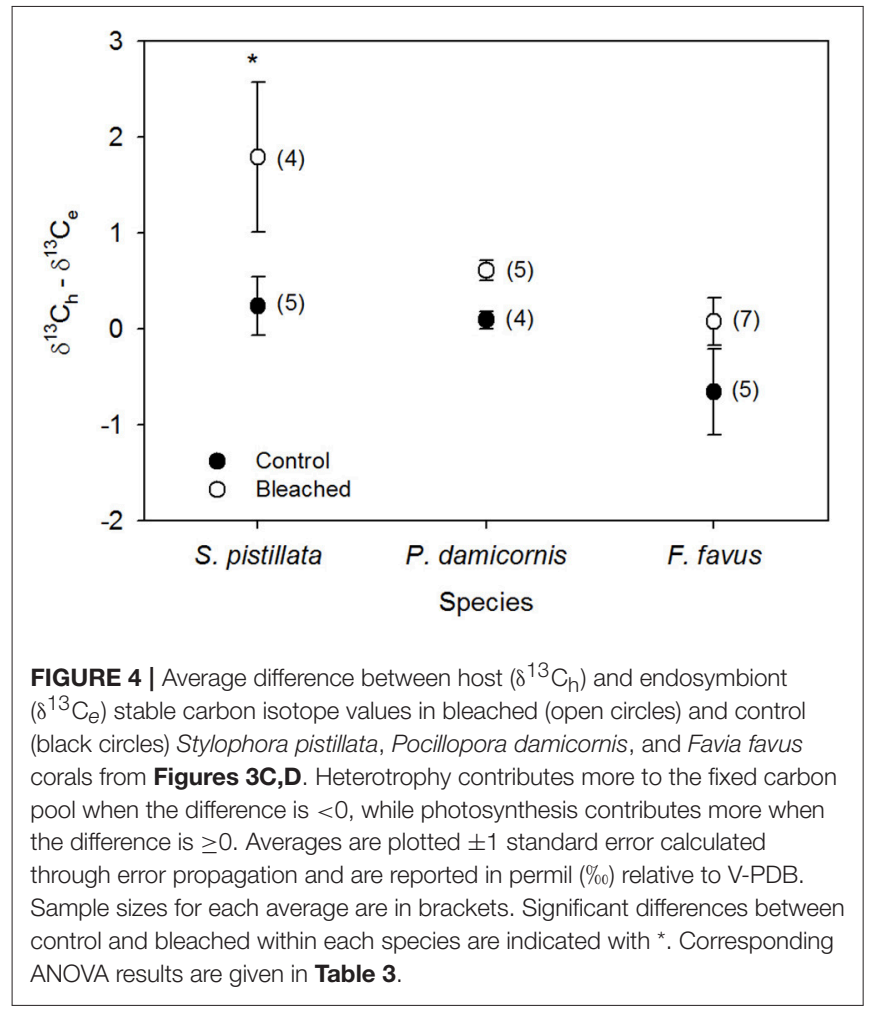

its heterotrophic intake under bleaching stress. Work by Ziegler et al. (2014) shows that Pocillopora are not heterotrophically plastic in response to changes in light, which may indicate
TABLE 4 | One-way ANOSIMs of physiological, isotopic, and both physiological and isotopic variables combined where each individual species and treatment was a factor allowing for pairwise tests of each species and treatment combination.

\begin{tabular}{lccc}
\hline Comparison & Physiology & Isotopes & $\begin{array}{c}\text { Physiology } \\
+ \text { Isotopes }\end{array}$ \\
\hline Global & $0.44(<0.001)$ & $0.67(<0.001)$ & $0.65(<0.001)$ \\
S. pistillata 26 vs. 32 & $0.56(0.008)$ & $0.79(0.018)$ & $0.66(0.008)$ \\
P. damicornis 26 vs. 32 & $0.14(0.200)$ & $0.01(0.450)$ & $0.26(0.143)$ \\
F. favus 26 vs. 32 & $0.66(0.001)$ & $0.29(0.025)$ & $0.64(0.001)$
\end{tabular}

Shown are the comparisons of interest. The models were all run with 999 permutations. $R$ values are listed with corresponding $p$-values in brackets. Note two samples had to be removed from the models with isotopes due to missing values.

that they would not be heterotrophically plastic in response to temperature changes either.

Schoepf et al. (2013) also found no changes in energy reserves and biomass in P. damicornis under control and elevated temperature conditions $\left(26.5\right.$ vs. $\left.29^{\circ} \mathrm{C}\right)$. This is surprising since corals of this genus are often among the most sensitive to thermal stress in other regions (Hueerkamp et al., 2001; Obura, 2001; McClanahan et al., 2004; Guest et al., 2012; Foster et al., 2014; Pisapia et al., 2016) and even suffer lipid losses when bleached (Rodriguez-Troncoso et al., 2016). But there are also cases where Pocillopora corals do not readily bleach compared to other species (Sebastian et al., 2009; Guest et al., 2012). Some evidence suggests that Pocillopora corals are beginning to acclimatize or adapt to thermal stress in Australia (Ulstrup et al., 2006; Maynard et al., 2008) and may have high acclimatization potential in northern 


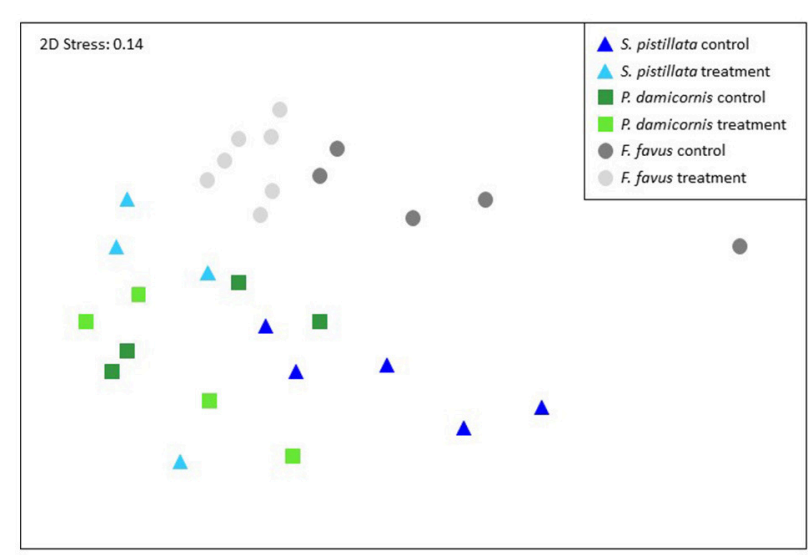

FIGURE 5 | Non-parametric multi-dimensional scaling ordination using the physiological and isotopic variables from 29 of the 31 corals. Two corals were not included because they did not have complete isotope data sets. The NMDS plots and corresponding ANOSIMS patterns were similar when build from just the physiology data (all 31 corals) or just the isotopic data (29 corals). Corresponding ANOSIMs results are given in Tables 4, 5.

TABLE 5 | Two-way ANOSIMs of physiological, isotopic, and both physiological and isotopic variables combined where species (S. pistillata, P. damicornis, F. favus) and treatment $\left(26^{\circ} \mathrm{C}, 32^{\circ} \mathrm{C}\right)$ were the factors.

\begin{tabular}{llll}
\hline Comparison & Physiology & Isotopes & $\begin{array}{l}\text { Physiology } \\
+ \text { Isotopes }\end{array}$ \\
\hline Global & $0.35(0.001)$ & $0.71(0.001)$ & $0.68(0.001)$ \\
S. pistillata vs. P. damicornis & $0.21(0.034)$ & $0.43(0.001)$ & $0.33(0.012)$ \\
P. damicornis vs. F. favus & $0.24(0.012)$ & $0.82(0.001)$ & $0.72(0.001)$ \\
S. pistillata vs. F. favus & $0.55(0.001)$ & $0.79(0.001)$ & $0.84(0.001)$ \\
$26^{\circ} \mathrm{C}$ vs. $32^{\circ} \mathrm{C}$ & $0.51(0.001)$ & $0.37(0.002)$ & $0.57(0.001)$ \\
\hline
\end{tabular}

The models were all run with 999 permutations. $R$ values are listed with corresponding $p$-values in brackets. All $p$-values were significant. Note two samples had to be removed from the models with isotopes due to missing values.

Red Sea populations (Sawall et al., 2015), though not through heterotrophic plasticity mechanisms (Ziegler et al., 2014). These findings suggest that $P$. damicornis in Eilat is a more resilient population to temperature-induced bleaching than those in other locations because (1) they can maintain their energy reserves, biomass, and calcification, and (2) appear to not be dependent on heterotrophy for meeting metabolic demand when bleached.

\section{Favia favus}

Bleached F. favus suffered declines in more physiological variables than either of the other two species with significant decreases in endosymbiotic algal density, mitotic divisions, protein, carbohydrates, total energy reserves, and biomass (Figures 1, 2), yet still maintained Chl a concentrations (Figure 1B). Even though photochemical efficiency $\left(\mathrm{F}_{\mathrm{v}} / \mathrm{F}_{\mathrm{m}}\right)$ tends to decline at elevated temperatures for $F$. favus from Eilat (Winters et al., 2006; Kuguru et al., 2007; Fine et al., 2013), the observed increase in $\delta^{13} \mathrm{C}_{\mathrm{e}}$ (Figure 3D) and maintained Chl $a$ levels suggests that some level of photosynthesis persisted while bleached. At the same time, F. favus catabolized its protein and carbohydrate reserves, which underlie the significant declines in total energy reserves and biomass (Figures 2 B-E), presumably to compensate for losses in photosynthetically fixed $\mathrm{C}$. Increases in $\delta^{13} \mathrm{C}_{\mathrm{h}}$ (Figure $3 \mathrm{C}$ ) suggest that the protein and carbohydrates catabolized during bleaching (Figures 2B,C) were isotopically depleted, or that in the absence of isotopically depleted zooplankton in the diet, coral tissues became progressively enriched. Further research is needed to evaluate the isotopic composition of protein and carbohydrates. However, since these corals were not supplied zooplankton during the experiment, it is likely that the enrichment in $\delta^{13} \mathrm{C}_{\mathrm{h}}$ observed here is at least in part a result of a lack of zooplankton availability. Although the ${ }^{13} \mathrm{C}_{\mathrm{h}-\mathrm{e}}$ did not change with bleaching in F. favus (Figure 4), it was lower overall than in S. pistillata and P. damicornis indicating a higher contribution of heterotrophic $C$ to its tissues in general, irrespective of bleaching, than in the other two species (Figure 4). This is consistent with field-based findings showing that F. favus allocates a higher proportion of heterotrophic $C$ to its lipids than does S. pistillata (Alamaru et al., 2009). In addition, some species are able to meet up to $36 \%$ of metabolic demand when bleached through the heterotrophic acquisition of dissolved and particulate organic carbon (Levas et al., 2013, 2016). The lower overall $\delta^{13} \mathrm{C}_{h-e}$ of $F$. favus suggests that when bleached it was able to take up dissolved and/or particulate organic carbon during the tank experiment to meet at least part of its metabolic demand heterotrophically. But any uptake in heterotrophic $\mathrm{C}$ was not enough to prevent large losses in protein and biomass. Had the corals been fed zooplankton, it is possible that F. favus might have maintained its energy reserves and biomass.

Finally, the skeletal isotopic signature in $F$. favus was unaffected by bleaching (Figures 3A,B), suggesting that calcification was maintained or at least did not decrease dramatically (Rodrigues and Grottoli, 2006). This is also consistent with the interpretation that some level of photosynthesis was maintained, since calcification is tightly linked to photosynthesis (see review by Allemand et al., 2011). Furthermore, in healthy corals, $\delta{ }^{18} \mathrm{O}_{\mathrm{s}}$ decreases by $\sim 0.2 \%$ per $1^{\circ} \mathrm{C}$ seawater warming (Weber and Woodhead, 1972; Wellington et al., 1996). Here a non-significant trend of a $0.36 \%$ decline in $\delta^{18} \mathrm{O}_{s}(P<0.085)$ suggests that $F$. favus skeletal isotopic signature recorded the seawater warming event, though not the $\sim 1.2 \%$ decline that would have be expected if it had accurately recorded the full $6^{\circ} \mathrm{C}$ increase in temperature. Nevertheless, the fact that a warming trend was recorded is further support that $F$. favus calcified throughout the experiment.

Overall, F. favus suffered significant declines in energy reserves and biomass, but maintained $\operatorname{Chl} a$, appears to have maintained calcification, and appears to have high baseline rates of heterotrophic $\mathrm{C}$ contributions to its tissues. The maintenance of Chl $a$ and the apparent high baseline heterotrophic capacity of this coral could explain why this genus experiences little to no mortality following bleaching events (McClanahan, 2004; Sutthacheep et al., 2013). In Hawaii, the mounding coral Porites lobata can also bleach severely, but recovers quickly due to a high baseline contribution of heterotrophic carbon to the diet (Palardy et al., 2008; Levas et al., 2013). Thus, the high baseline heterotrophic capacity of the mounding coral F. favus may 
facilitate the rapid recovery and low mortality of this species following bleaching stress, and allow it to persist into the future, despite its initial dramatic energy reserve and biomass losses when bleached.

\section{SUMMARY}

The corals found in the northern tip of the Gulf of Aqaba are able to tolerate temperatures well above their thermal summer maximum for extended periods of time without bleaching, making them temperature-tolerant super-corals. Unlike most corals that bleach after a 4-DHW exposure and experience significant mortality after 8-DHW, all three species of corals here bleached only after being exposed to the equivalent of 32DHW. However, the physiological and biogeochemical responses to bleaching were species-specific. $P$. damicornis and S. pistillata maintained their total energy reserves and biomass while $F$. favus lost total energy reserves and biomass. Interestingly, total energy reserves in all three species of Eilat corals, irrespective of bleaching status, were higher than levels found in corals that were the most susceptible to repeat bleaching in the Caribbean (Grottoli et al., 2014) and consistent with findings that high energy reserves is a common trait found among the most thermally tolerant corals (Rodrigues and Grottoli, 2007; Anthony et al., 2009; Grottoli et al., 2014; Schoepf et al., 2015). While, we found no isotopic evidence of increases in heterotrophy as a mechanism for coping with the declines in photoautotrophically fixed carbon supply in bleached corals, the isotopic signature of $F$. favus suggests that it has a high baseline input of heterotrophic $C$, which could underlie its low mortality rate following bleaching events (McClanahan, 2004; Sutthacheep et al., 2013), despite its energy reserve and biomass losses. In addition, endosymbiont type switching or shuffling to acquire or increase thermally tolerant Symbiodinium clade D is probably not an underlying trait to Eilat super-coral thermal tolerance as Symbiodinium D has never been detected in this population of corals (Fine et al., 2013) even though it is present in more southern regions of the Red Sea (Baker et al., 2004; Ziegler et al., 2014). These findings support our hypothesis that energy reserves, biomass, and

\section{REFERENCES}

Alamaru, A., Loya, Y., Brokovich, E., Yam, R., and Shemesh, A. (2009). Carbon and nitrogen utilization in two species of Red Sea corals along a depth gradient: Insights from stable isotope analysis of total organic material and lipids. Geochim. Cosmochim. Acta 73, 5333-5342. doi: 10.1016/j.gca.2009.06.018

Allemand, D., Tambutte, E., Zoccola, D., and Tambutte, S. (2011). "Coral calcifrication, cells to reefs," in Coral Reefs: An Ecosystem in Transition, eds Z. Dubinsky and N. Stambler (New York, NY: Springer), 119-150.

Anthony, K. R. N., Hoogenboom, M. O., Maynard, J. A., Grottoli, A. G., and Middlebrook, R. (2009). Energetics approach to predicting mortality risk from environmental stress: a case study of coral bleaching. Funct. Ecol. 23, 539-550. doi: 10.1111/j.1365-2435.2008.01531.x

Baker, A. C., Starger, C. J., McClanahan, T. R., and Glynn, P. W. (2004). Corals' adaptive response to climate change. Nature 430:741. doi: 10.1038/430741a

Baumann, J., Grottoli, A. G., Hughes, A. D., and Matsui, Y. (2014). Photoautotrophic and heterotrophic carbon in bleached and non-bleached heterotrophic capacity are central traits to bleaching tolerance in all corals including northern Gulf of Aqaba super-corals, though corals need not have all of these traits to be thermally resilient. In addition, these resilience traits have been identified in a number of coral species throughout the world, suggesting that these phenotypic traits for thermal tolerance may be universal. But, Eilat coral can tolerate much more severe warming events than other populations of corals with similar phenotypic traits, supporting the finding that the Eilat coral thermal tolerance is also driven by the underlying genetics of these coral populations (Fine et al., 2013). Additional study is needed to confirm these findings where the corals are provided zooplankton throughout the experiment. Irrespective of the underlying mechanism for thermal tolerance, super-corals from the northern portion of the Gulf of Aqaba could be used for restocking reefs in other regions where bleaching events have dramatically reduced coral abundance. This may be particularly relevant for Stylophora and $P$. damicornis corals as they are among those most likely to die following bleaching events in some regions (e.g., Glynn, 1984; Glynn et al., 2001; McClanahan, 2004).

\section{AUTHOR CONTRIBUTIONS}

AG conceived of the study and secured the funding. DT and GW executed the experiment. AG analyzed the samples, statistically analyzed the data, interpreted the results, and wrote the manuscript. DT contributed to the revising of the manuscript.

\section{FUNDING}

Partial funding was provided by startup funds from the University of Pennsylvania and the Ohio State University and by funding from National Science Foundation - Biological Oceanography grant \#1459536.

\section{ACKNOWLEDGMENTS}

We would like to thank Ryan Moyer, Dan Mucciarone, and Lindsey Swiaki for their assistance.

coral lipid acquisition and storage. J. Exp. Biol. Ecol. 461, 469-478. doi: 10.1016/j.jembe.2014.09.017

Berkelmans, R., and van Oppen, M. J. H. (2006). The role of zooxanthellae in the thermal tolerance of corals: a 'nugget of hope' for coral reefs in an era of climate change. Proc. R. Soc. B Biol. Sci. 273, 2305-2312. doi: 10.1098/rspb.2006.3567

Brown, B. E. (1997). Coral bleaching: causes and consequences. Coral Reefs 16 (Suppl.), s129-s138. doi: 10.1007/s003380050249

Buddemeier, R. W., Kleypas, J. A., and Aronson, R. B. (2004). Coral Reefs and Global Climate Change: Potential Contributions of Climate Change to Stresses on Coral Reef Ecosystems. Arlington, VA: Pew Center on Global Climate Change.

Byler, K., Carmi-Veal, M., Fine, M., and Goulet, T. (2013). Multiple symbiont acquisition strategies as an adaptive mechanism in the coral Stylophora pistillata. PLoS ONE 8:e59596. doi: 10.1371/journal.pone.0059596

Cantin, N., Cohen, A. L., Karnauskas, K., Tarrant, A., and McCorkle, D. (2010). Ocean warming slows coral growth in the central Red Sea. Science 329, 322-325. doi: $10.1126 /$ science. 1190182 
Chua, C., Leggat, W., Moya, A., and Baird, A. H. (2013). Temperature affects the early life history stages of corals more than near future ocean acidification. Mar. Ecol. Prog. Ser. 475, 85-92. doi: 10.3354/meps 10077

Clarke, K., and Gorley, R. (2006). Primerv6: User Manual/Turorial. Plymouth, UK: PRIMER-E Ltd.

Clausen, C. D., and Roth, A. A. (1975). Effect of temperature and temperature adaptation on calcification rate in the hermatypic coral Pocillopora damicornis. Mar. Biol. 33, 93-100. doi: 10.1007/BF00390713

Dubois, M., Giles, K. A., Hamilton, J. K., Rebers, P. A., and Smith, F. (1956). Colorimetric method for determination of sugars and related substances. Anal. Chem. 28, 350-356. doi: 10.1021/ac60111a017

Eakin, C. M., Lough, J. M., and Heron, S. F. (2009). "Climate variability and change: monitoring data and evidence for increased coral bleaching stress," in Coral Bleaching: Patterns, Processes, Causes and Consequences, eds M. J. H. van Oppen and J. M. Lough (Berlin: Springer-Verlag), 41-67.

Edmunds, P. J., and Gates, R. D. (2002). Normalizing physiological data for scleractinian corals. Coral Reefs 21, 193-197. doi: 10.1007/s00338-002-0214-0

Epstein, S., Buchsbaum, R., Lowenstam, H. A., and Urey, H. C. (1953). Revised carbonate-water isotopic temperature scale. Bull. Geol. Soc. Am. 64, 1315-1326. doi: 10.1130/0016-7606(1953)64[1315:RCITS]2.0.CO;2

Ferrier-Pages, C., Rottier, C., Beraud, E., and Levy, O. (2010). Experimental assessment of the feeding effort of three scleractinian coral species during a thermal stress: effect on the rates of photosynthesis. J. Exp. Mar. Biol. Ecol. 390, 118-124. doi: 10.1016/j.jembe.2010.05.007

Fine, M., Gildor, H., and Genin, A. (2013). A coral reef refuge in the Red Sea. Glob. Chang. Biol. 19, 3640-3647. doi: 10.1111/gcb.12356

Foster, T., Short, J., Falter, J., Ross, C., and McCulloch, M. (2014). Reduced calcification in Western Australian corals during anomalously high summer water temperatures. J. Exp. Mar. Biol. Ecol. 461, 133-143. doi: 10.1016/j.jembe.2014.07.014

Frieler, K., Meinshausen, M., Golly, A., Mengel, M., Lebek, K., Donner, S. D., et al. (2012). Limiting global warming to $2^{\circ} \mathrm{C}$ is unlikely to save most coral reefs. Nat. Clim. Chang. 3, 165-170. doi: 10.1038/nclimate1674

Glynn, P. W. (1984). Widespread coral mortality and the 1982-83 El Nino warming event. Environ. Conserv. 2, 133-146. doi: 10.1017/S03768929000 13825

Glynn, P. W., Mate, J. L., Baker, A. C., and Calderon, M. O. (2001). Coral bleaching and mortality in Panama and Ecuador during the 1997-1998 El Nino Southern Oscillation event: spatial/temporal patterns and comparisons with the 1982-1983 event. Bull. Mar. Sci. 69, 79-109.

Gnaiger, E., and Bitterlich, G. (1984). Proximate biochemical composition and caloric content calculated from elemental CHN analysis: a stoichiometricc oncept. Oecologia 62, 289-298. doi: 10.1007/BF003 84259

Grottoli, A. G. (2002). Effect of light and brine shrimp on skeletal delta C-13 in the Hawaiian coral Porites compressa: a tank experiment. Geochim. Cosmochim. Acta 66, 1955-1967. doi: 10.1016/S0016-7037(01)00901-2

Grottoli, A. G., Rodrigues, L. J., and Juarez, C. (2004). Lipids and stable carbon isotopes in two species of Hawaiian corals, Porites compressa and Montipora verrucosa, following a bleaching event. Mar. Biol. 145, 621-631. doi: 10.1007/s00227-004-1337-3

Grottoli, A. G., Rodrigues, L. J., and Palardy, J. E. (2006). Heterotrophic plasticity and resilience in bleached corals. Nature 440, 1186-1189. doi: $10.1038 /$ nature 04565

Grottoli, A. G., and Wellington, G. M. (1999). Effect of light and zooplankton on skeletal $\delta^{13} \mathrm{C}$ values in the eastern Pacific corals Pavona clavus and Pavona gigantea. Coral Reefs 18, 29-41. doi: 10.1007/s003380050150

Grottoli, A., and Rodrigues, L. (2011). Bleached Porites compressa and Montipora capitata corals catabolize $\delta^{13} \mathrm{C}$-enriched lipids. Coral Reefs 30, 687-692. doi: 10.1007/s00338-011-0756-0

Grottoli, A., Warner, M., Levas, S., Aschaffenburg, M., Schoepf, V., McGiinley, M., et al. (2014). The cumulative impact of annual coral bleaching can turn some coral species winners into losers. Glob. Chang. Biol. 20, 3823-3833. doi: $10.1111 / \mathrm{gcb} .12658$

Guest, J. R., Baird, A. H., Maynard, J. A., Muttaqin, E., Edwards, A. J., Campbell, S. J., et al. (2012). Contrasting patterns of coral bleaching susceptibility in 2010 suggest an adaptive response to thermal stress. PLoS ONE 7:33353. doi: 10.1371 /journal.pone. 0033353
Heron, S. F., Maynard, J. A., van Hooidonk, R., and Eakin, C. M. (2016). Warming trends and bleaching stress of the world's coral reefs 1985-2012. Nat. Sci. Rep. 6:38402. doi: $10.1038 /$ srep 38402

Hoegh-Guldberg, O. (1999). Climate change, coral bleaching and the future of the world's coral reefs. Mar. Freshw. Res. 50, 839-866. doi: 10.1071/MF99078

Hoegh-Guldberg, O. (2011). "The impact of climate change on coral reef ecosystems," in Corals Reefs: an Ecosystem in Transition, eds Z. Dubinsky and N. Stambler (New York, NY: Springer Science+Business Media), 391-403.

Hoegh-Guldberg, O., Mumby, P. J., Hooten, A. J., Steneck, R. S., Greenfield, P., Gomez, E., et al. (2007). Coral reefs under rapid climate change and ocean zcidification. Science 318, 1737-1742. doi: 10.1126/science.1152509

Hueerkamp, C., Glynn, P. W., D'Croz, L., Mate, J. L., and Colley, S. B. (2001). Bleaching and recovery of five eastern Pacific corals in an El Nino-related temperature experiment. Bull. Mar. Sci. 69, 215-236.

IPCC (2013). Summary for Policymakers. Cambridge, UK; New York, NY: Cambridge University Press.

Jeffrey, S. W., and Humphrey, G. F. (1975). New spectrophotometric equations for determining chlorophylls $a, b, c 1$ and $c 2$ in higher plants, algae and natural phytoplankton. Biochem. Physiol. Pflanzen 167, 191-194. doi: 10.1016/S00153796(17)30778-3

Johannes, R. E., and Wiebe, W. J. (1970). Method for determination of coral tissue biomass and composition. Limnol. Oceanogr. 15, 822-824. doi: 10.4319/lo.1970.15.5.0822

Karako-Lampert, S., Katcoff, D., Achituv, Y., Dubinsky, Z., and Stambler, N. (2004). Do clades of symbiotic dinoflagellates in scleractinian corals of the Gulf of Eilat (Red Sea) differ from those of other coral reefs? J. Exp. Mar. Biol. Ecol. 311, 301-314. doi: 10.1016/j.jembe.2004.05.015

Kim, S.-T., and O'Neil, J. R. (1997). Temperature dependence of d18O. Geochim. Cosmochim. Acta 61, 3461-3475. doi: 10.1016/S0016-7037(97)00169-5

Kuguru, B., Winters, G., Beer, S., Santos, S., and Chadwick, N. (2007). Adaptation strategies of the corallimorpharian Rhodactis rhodostoma to irradiance and temperature. Mar. Biol. 151, 1287-1298. doi: 10.1007/s00227-006-0589-5

Kvitt, H., Rosenfeld, H., and Tchernov, D. (2016). The regulation of thermal stress induced apoptosis in corals reveals high similarities in gene expression and function to higher animals. Sci. Rep. 6:30359. doi: 10.1038/srep30359

Kvitt, H., Rosenfeld, H., Zandbank, K., and Tchernov, D. (2014). Regulation of apoptotic pathways by Stylophora pistillata (Anthozoa, Pocilloporidae) to survive thermal stress and bleaching. PLoS ONE 6:e28665. doi: 10.1371/journal.pone.0028665

Levas, S., Grottoli, A. G., Hughes, A. D., Osburn, C., and Matsui, Y. (2013). Physiological and biogeochemical traits of bleaching and recovery in the mounding species of coral Porites lobata: implications for resilience in mounding corals. PLoS ONE 8:e63267. doi: 10.1371/journal.pone.0063267

Levas, S., Grottoli, A. G., Schoepf, V., Aschaffenburg, M., Baumann, J., Bauer, J., et al. (2016). Can heterotrophic uptake of dissolved organic carbon and zooplankton mitigate carbon budget deficits in annually bleached corals? Coral Reefs 35, 495-506. doi: 10.1007/s00338-015-1390-z

Loya, Y., Sakai, K., Yamazato, K., Nakano, Y., Sambali, H., and van Woesik, R. (2001). Coral bleaching: the winners and the losers. Ecol. Lett. 4, 122-131. doi: 10.1046/j.1461-0248.2001.00203.x

Marsh, J. A. (1970). Primary productivity of reef-building calcareous red algae. Ecology 51, 255-263. doi: 10.2307/1933661

Maynard, J. A., Anthony, K., Marshall, P., and Masiri, I. (2008). Major bleaching events can lead to increased thermal tolerance in corals. Mar. Biol. 155, 173-182. doi: 10.1007/s00227-008-1015-y

McClanahan, T., Baird, A. H., Marshall, P., and Toscano, M. (2004). Comparing bleaching and mortality responses of hard corals between southern Kenya and the Great Barrier Reef, Australia. Mar. Pollut. Bull. 48, 327-335. doi: 10.1016/j.marpolbul.2003.08.024

McClanahan, T. R. (2004). The relationship between bleaching and mortality of common corals. Mar. Biol. 144, 1239-1245. doi: 10.1007/s00227-003-1271-9

McConnaughey, T. (1989). ${ }^{13} \mathrm{C}$ and ${ }^{18} \mathrm{O}$ isotopic disequilibrium in biological carbonates: I. Patterns Geochim. Cosmochim. Acta 53, 151-162. doi: 10.1016/ 0016-7037(89)90282-2

Muscatine, L., Porter, J. W., and Kaplan, I. R. (1989). Resource partitioning by reef corals as determined from stable isotope composition. I. $\delta^{13} \mathrm{C}$ of zooxanthellae and animal tissue vs depth. Mar. Biol. 100, 185-193. doi: 10.1007/BF003 91957 
Obura, D. O. (2001). Can differential bleaching and mortality among coral species offer useful indicators for assessment and management of reefs under stress? Bull. Mar. Sci. 69, 421-442.

Omori, M., Fukami, H., Kobinata, H., and Hatta, M. (1999). Significant drop of fertilization of Acropora corals in 1999: an after-effect of heavy coral bleaching? Limnol. Oceanogr. 46, 704-706. doi: 10.4319/1o.2001.46.3.0704

Palardy, J. E., Rodrigues, L. J., and Grottoli, A. G. (2008). The importance of zooplankton to the daily metabolic carbon requirements of healthy and bleached corals at two depths. J. Exp. Mar. Biol. Ecol. 367, 180-188. doi: 10.1016/j.jembe.2008.09.015

Paldor, N., and Anati, D. (1979). Seasonal variations of temperature and salinity in the Gulf of Elat (Aqaba). Deep-Sea Res. 26, 661-672. doi: 10.1016/0198-0149(79)90039-6

Pisapia, C., Burn, D., Yoosuf, R., Najeeb, A., Anderson, K., and Pratchett, M. (2016). Coral recovery in the central Maldives archipelago since the last major mass-bleaching, in 1998. Nat. Sci. Rep. 6:34720. doi: 10.1038/srep34720

Quinn, G. P., and Keough, M. J. (2002). Experimental Design and Data Analysis for Biologists. New York, NY: Cambridge University Press.

Rodrigues, L. J., and Grottoli, A. G. (2006). Calcification rate and the stable carbon, oxygen, and nitrogen isotopes in the skeleton, host tissue, and zooxanthellae of bleached and recovering Hawaiian corals. Geochim. Cosmochim. Acta 70, 2781-2789. doi: 10.1016/j.gca.2006.02.014

Rodrigues, L. J., and Grottoli, A. G. (2007). Energy reserves and metabolism as indicators of coral recovery from bleaching. Limnol. Oceanogr. 52, 1874-1882. doi: 10.4319/lo.2007.52.5.1874

Rodriguez-Troncoso, A., Carpizo-Ituarte, E., and Cupul-Magana, A. (2016). Physiological response to high temperature in the Tropical Eastern Pacific coral Pocillopora verrucosa. Mar. Ecol. 37, 1168-1175. doi: 10.1111/maec.12392

Rowan, R., Knowlton, N., Baker, A., and Jara, J. (1997). Landscape ecology of algal symbionts creates variation in episodes of coral bleaching. Nature 388, 265-269. doi: $10.1038 / 40843$

Sawall, Y., Al-Sofyani, A., Hohn, S., Banguera-Hinestroza, E., Voolstra, C., and Wahl, M. (2015). Extensive phenotypic plasticity of a Red Sea coral over a strong latitudinal temperature gradient suggests limited acclimatization potential to warming. Nat. Sci. Rep. 5:8940. doi: 10.1038/srep08940

Schoepf, V., Grottoli, A. G., Levas, S. J., Aschaffenburg, M., Baumann, J., Matsui, Y., et al. (2015). Annual coral bleaching and the long-term recovery capacity of coral. Proc. R. Soc. B 282:20151887. doi: 10.1098/rspb.2015.1887

Schoepf, V., Grottoli, A., Warner, M., Cai, W., Melman, T., Hoadley, K., et al. (2013). Coral energy reserves and calcification in a high- $\mathrm{CO}_{2}$ world at two temperatures. PLoS ONE 8:e75049. doi: 10.1371/journal.pone.0075049

Sebastian, C., Sink, K., McClanahan, T., and Cowan, D. (2009). Bleaching response of corals and their Symbiodinium communities in southern Africa. Mar. Biol. 156, 2049-2062. doi: 10.1007/s00227-009-1236-8

Shlesinger, Y., and Loya, Y. (1985). Coral community reproductive patterns: Red Sea versus the Great Barrier Reef. Science 228, 1333-1335. doi: $10.1126 /$ science. 228.4705 .1333

Smith, P. K., Krohn, R. I., Hermanson, G. T., Mallia, A. K., Gartner, F. H., Provenzano, M. D., et al. (1985). Measurement of protein using bicinchonic acid. Anal. Biochem. 150, 76-85. doi: 10.1016/0003-2697(85) 90442-7

Sutthacheep, M., Yucharoen, M., Klinthong, W., Pengsakun, S., Sangmanee, K., and Yeemin, T. (2013). Impacts of the 1998 and 2010 mass coral bleaching events on the Western Gulf of Thailand. Deep-Sea Res. 96, 25-31. doi: 10.1016/j.dsr2.2013.04.018

Tchernov, D., Gorbunov, M. Y., de Vargas, C., Yadav, S. N., Milligan, A. J., Haggblom, M., et al. (2004). Membrane lipids of symbiotic algae are diagnostic of sensitivity to thermal bleaching in corals. Proc. Natl. Acad. Sci. U.S.A. 101, 13531-13535. doi: 10.1073/pnas.0402907101
Tchernov, D., Kvitt, H., Haramaty, L., Bibby, T. S., Gorbunov, M. Y., Rosenfeld, H., et al. (2011). Apoptosis and the selective survival of host animals following thermal bleaching in zooxanthellate corals. Proc. Natl. Acad. Sci. U.S.A. 108, 9905-9909. doi: 10.1073/pnas.1106924108

Tremblay, P., Naumann, M. S., Sikorski, S., Grover, R., and Ferrier-Pages, C. (2012). Experimental assessment of organic carbon fluxes in the scleractinian coral Stylophora pistillata during a thermal and photo stress event. Mar. Ecol. Prog. Ser. 453, 63-77. doi: 10.3354/meps09640

Ulstrup, K. E., Berkelmans, R., Ralph, P. J., and Van Oppen, M. J. H. (2006). Variation in bleaching sensitivity of two coral species across a latitudinal gradient on the Great Barrier Reef: the role of zooxanthellae. Mar. Ecol. Prog. Ser. 314, 135-148. doi: 10.3354/meps314135

van Hooidonk, R., Maynard, J. A., and Planes, S. (2013). Temporary refugia for coral reefs in a warming world. Nat. Clim. Chang. 3, 508-511. doi: 10.1038/nclimate1829

van Hooidonk, R., Maynard, J., Manzello, D., and Planes, S. (2014). Opposite latitudinal gradients in projected ocean acidification and bleaching impacts on coral reefs. Glob. Chang. Biol. 20, 103-112. doi: 10.1111/gcb.12394

Veron, J. E. N., Hoeg-Guldberg, O., Lenton, T. M., Lough, J. M., Obura, D. O., Pearce-Kelly, P., et al. (2009). The coral reef crisis: The critical importance of $<350 \mathrm{ppm} \quad \mathrm{CO}_{2}$. Mar. Pollut. Bull. 58, 1428-1436. doi: 10.1016/j.marpolbul.2009.09.009

Weber, J. N., and Woodhead, P. M. J. (1972). Temperature dependence of oxygen-18 concentration in reef coral carbonates. J. Geophys. Res. 77, 463-473. doi: 10.1029/JC077i003p00463

Wellington, G. M., Dunbar, R. B., and Merlen, G. (1996). Calibration of stable oxygen isotope signatures in Galapagos corals. Paleoceanography 11, 467-480. doi: 10.1029/96PA01023

Winer, B. (1971). Statistical Principles in Experimental Design. New York, NY: McGraw-Hill.

Winters, G., Beer, S., Ben Zvi, B., Brickner, I., and Loya, Y. (2009). Spatial and temporal photoacclimation of Stylophora pistillata: zooxanthella size, pigmentation, location and clade. Mar. Ecol. Prog. Ser. 384, 107-119. doi: $10.3354 /$ meps 08036

Winters, G., Loya, Y., and Beer, S. (2006). In situ measured seasonal variations in Fv/Fm of two common Red Sea corals. Coral Reefs 25, 593-598. doi: 10.1007/s00338-006-0144-3

Ziegler, M., Arif, C., Burt, J., Dobretsov, C., LaJeunesse, T., and Voolstra, C. (2017). Biogeography and molecular diversity of coral symbionts in the genus Symbiodinium around the Arabian Peninsula. J. Biogeogr. 44, 674-686. doi: $10.1111 /$ jbi.12913

Ziegler, M., Roder, C., Buchyel, C., and Voolstra, C. (2014). Limits to physiological plasticity of the coral Pocillopora verrucosa from the central Red Sea. Coral Reefs 33, 1115-1129. doi: 10.1007/s00338-014-1192-8

Conflict of Interest Statement: The authors declare that the research was conducted in the absence of any commercial or financial relationships that could be construed as a potential conflict of interest.

The reviewer MN and handling Editor declared their shared affiliation, and the handling Editor states that the process nevertheless met the standards of a fair and objective review.

Copyright $\odot 2017$ Grottoli, Tchernov and Winters. This is an open-access article distributed under the terms of the Creative Commons Attribution License (CC BY). The use, distribution or reproduction in other forums is permitted, provided the original author(s) or licensor are credited and that the original publication in this journal is cited, in accordance with accepted academic practice. No use, distribution or reproduction is permitted which does not comply with these terms. 